\title{
THE PRESIDENT'S POWER OF INTERPRETATION: IMPLICATIONS OF \\ A UNIFIED THEORY OF CONSTITUTIONAL LAW
}

\author{
GEOFFREY P. MiLleR*
}

\section{INTRODUCTION}

This article offers a model of the nature, sources, and extent of the president's power to interpret the Constitution. The model is grounded in a theory of constitutional law that seeks to unify the two great systems of U.S. fundamental law, the system of rights and the system of structure. ${ }^{1}$

As discussed in the body of this article, unified theory supplements the existing analysis of presidential power in two ways. First, unified theory suggests the utility of cross-fertilization between the systems of rights and structure-of importing the value of liberty from the system of rights and applying it to the system of structure, and likewise, of importing the principle of checks and balances from the system of structure and applying it to the system of rights. Second, unified theory suggests the possibility of devising broader concepts that apply to both systems. Energy in government and the avoidance of faction are two overarching concepts in my version of unified theory.

Unified theory raises subtle problems with respect to the president's power of constitutional interpretation. One cannot say that the president has plenary power to interpret the Constitution, nor can one say flatly that the president's power of interpretation is subject to the overriding power of the federal courts, or of Congress. Instead, the nature and extent of the president's power of

Copyright $@ 1993$ by Law and Contemporary Problems

* Kirkland \& Ellis Professor of Law, University of Chicago Law School.

I would like to thank Neal Devins, Harold Krent, and Michael Paulsen for superb comments, Chris Bryant for valuable research assistance, and the Sarah Scaife and the Lynde and Harry Bradley Foundations for financial support.

1. I proposed such a unified theory in Geoffrey P. Miller, Rights and Structure in Constitutional Theory, 8 SOC. PHIL. \& POL'Y 196 (1991), reprinted in REASSESSING CIVIL RIGHTS (Ellen Frankel Paul et al. eds., 1991)[hereinafter Constitutional Theory]. For an analysis of the concept of the unitary executive within the framework of unified theory, see Geoffrey P. Miller, The Unitary Executive in a Unified Theory of Constitutional Law, 15 CARDOZO L. REV. 201 (1993) [hereinafter Unitary Executive]. See also Geoffrey P. Miller, Liberty and Constitutional Architecture: The Rights-Structure Paradigm, 16 HARV. J.L. \& PUB. POL'Y 87 (1993) [hereinafter Rights-Structure]. For criticism of the unified theory approach by a noted federal judge, see Frank H. Easterbrook, Unitary Executive Interpretation: $A$ Comment, 15 CARDOZO L. REV. 313, 315-20 (1993). For a more favorable assessment, see Michael Fitts, Ways to Think About the Unitary Executive: A Comment on Approaches to Government Structure, 15 CARDOZO L. REV. 323, 329-32 (1993). 
constitutional interpretation depends on the issue being addressed and the particular political and procedural context in which the question arises.

This area of constitutional law and practice is murky, but it may be possible to identify some of the relevant considerations. Among these are the following:

Energy in Government. As an incident to the value of energy in government, ${ }^{2}$ the president enjoys a power of interpretation flowing from the duty to execute the laws. The president cannot execute laws, including the law of the Constitution, unless the laws are interpreted; in many cases the president has no choice but to interpret the Constitution independently, without guidance from the Supreme Court or anyone else. Thus, the executive power necessarily includes a power of legal interpretation that does not depend on the vesting of judicial power in the Supreme Court under Article III of the Constitution. ${ }^{3}$

The scope of the president's power of interpretation also depends, in part, on whether the issue at hand involves situations where the value of energy in government is strongly implicated, such as domestic lawlessness or threats from foreign powers. When domestic lawlessness or foreign threats are present, energy in government supports broader presidential interpretive powers. Conversely, when domestic lawlessness or foreign threats are absent, energy in government does not support broad interpretive powers.

Faction-Avoidance. Unified theory also favors constitutional arrangements that limit the influence of political factions on U.S. public life. Thus, the president's interpretive powers should be constrained to limit the influence of such groups. The president should enjoy relatively broad powers to interpret the law in a fashion that checks the power of special interest lobbies, but only a relatively narrow scope of discretion to interpret the law so as to enhance special interest power.

Liberty. Unified theory limits the president's interpretive powers when the issue endangers individual liberties-either liberties of the person or rights of property. Therefore, the president should favor interpretations that tend to protect individual liberties over interpretations that tend to undermine them.

Checks and Balances. Finally, the principle of checks and balances under unified theory suggests that the president enjoys broader interpretive flexibility when the issue in question does not implicate the powers of other branches. If, on the other hand, the president's decision directly affects the powers of Congress or the Supreme Court, the president should narrowly interpret constitutional provisions that favor executive authority, and broadly interpret constitutional provisions that limit executive authority vis-à-vis the other

2. See infra note 69 and accompanying text.

3. U.S. CONST. art. III, $\$ 1$. 
branches. This article refers to this maxim as the principle of deferential interpretation.

The principle of deferential interpretation has a variety of more specific implications. When power relations with the federal courts are implicated, the president's interpretive flexibility largely depends on whether the federal courts have developed doctrine on the matter. If the matter is one of first impression, the president enjoys relatively broad interpretive flexibility. If, however, the federal courts have established settled rules, the president's interpretive discretion is more limited. The constraints on presidential interpretive authority also depend on the identity of the courts that have addressed the question. Greater deference is owed to the Supreme Court than to lower federal courts. The extent to which the courts have definitively settled the question is also relevant: greater deference is owed to a case directly on point than to one which differs in significant respects from the matter at issue.

The president's power of interpretation also depends, in part, on whether or not the matter arises in litigation. The president enjoys significant freedom when presenting constitutional arguments to a federal court. Under the system of checks and balances, it is then the court, not the president, that ultimately makes judicial decisions. Once a federal court has ruled, however, and all avenues of higher review have been exhausted, unified theory suggests that the court's judgment binds the president, except in unusual cases in which the integrity of the nation is threatened.

When the president interprets the Constitution outside the litigation context, the president should ordinarily defer to settled judicial interpretations, since, given the court's role as impartial decisionmaker and protector of individual liberty, settled interpretations are likely to protect individual liberties and to reduce the influence of faction. However, unified theory would allow the president to reject such interpretations if he or she concludes that doing so is necessary to protect citizens against domestic expropriation or violence, or to conduct foreign affairs or military operations. If the president does reject a settled judicial interpretation and the matter is thereafter tested in court, the president would ordinarily be bound, as described above, to respect a final judgment of the federal courts even if the judgment is contrary to the president's own views.

The principle of checks and balances under unified theory also suggests some inferences about presidential interpretive authority vis-à-vis Congress. The scope of the president's authority to interpret the Constitution should be relatively greater with respect to proposed legislation than with respect to enacted legislation. Just as the president has very broad authority to present his or her own view of the Constitution to a court for its decision, he or she also has wideranging powers to object to proposed legislation on constitutional grounds. With respect to enacted legislation, however, the president should conclude that a provision is unconstitutional, and therefore unenforceable by the executive branch, only when there are strong reasons, such as a compelling need to protect 
individual liberties, conduct foreign affairs, or safeguard the national defense, for rejecting the judgment of Congress.

Finally, unified theory may have some bearing on the question of whether the president has authority to bind himself or herself, or subsequent presidents, to particular interpretations of the Constitution. The president has more flexibility in interpreting the Constitution if the matter is one of first impression for the executive branch than if there exist prior pronouncements from responsible executive officials.

For the most part, the interpretive principles set forth in this article are consistent with reasonable intuitions: most people would agree, for example, that the president should not ordinarily disobey a direct mandate of the Supreme Court in a case properly within the Court's jurisdiction. Similarly, most people would probably agree that the president has greater powers to interpret the Constitution in matters relating to foreign affairs or national defense than he or she has in cases involving purely domestic issues. The other principles set forth above, explored in greater detail below, also seem to accord well with sensible intuitions about the scope of the president's authority to interpret the Constitution. The theory's general consistency with reasonable intuitions is an advantage of unified theory over other models, which tend to yield less-modulated results, and which are often at odds with reasonable intuitions. ${ }^{4}$

The body of this article consists of three parts. Part II addresses some defects of prior theoretical work on this area. Part III describes the nature and implications of a unified theory of constitutional law. Part IV argues that unified theory provides a valuable articulation of the president's rights and obligations in this complex and important area of fundamental law.

\section{THEORIES OF PRESIDENTIAL CONSTITUTIONAL INTERPRETATION}

Before discussing a unified theory of presidential constitutional interpretation, it is useful to consider the strengths and weaknesses of alternative theories. As will be seen, a noteworthy feature of many of these theories is their absolutism: They tend either to accord the president virtually unfettered discretion on questions of constitutional interpretation, or rigidly to circumscribe the president's interpretive powers within Supreme Court jurisprudence. There are few, if any, existing theories that provide a satisfying account of the limits of presidential interpretive authority while, at the same time, remaining consistent with reasonable intuitions about these problems. ${ }^{5}$ Further, existing theories suffer from the defect that they usually consider only the impact of judicial decisions on the scope of presidential interpretive authority. While this problem is no doubt fundamental, an adequate theory of presidential interpretive power

4. See infra notes 8-35.

5. On consistency with reasonable intuitions, see JOHN RAWLS, A THEORY OF JUSTICE 48-51 (1971) (reflective equilibrium). 
should also address other considerations that may have little to do with the power relations between the president and the federal judiciary.

\section{A. The Absolutism of Existing Theories}

A principal defect of existing theories is that they tend to fall down one or the other of two slippery slopes. The executive supremacist school recognizes a nearly unfettered power of presidential interpretation, while the judicial supremacist school strictly requires the president to follow the interpretations set forth by federal courts. ${ }^{6}$

1. Judicial Supremacists. Judicial supremacists probably represent the majority view among U.S. legal academics. Their position, broadly speaking, is that the president must treat U.S. Supreme Court decisions as authoritative in the same way a lower federal court judge would treat such decisions. The judicial supremacy position is grounded in the view that the Supreme Court is the final authority in our system on the meaning of the Constitution. ${ }^{7}$ A corollary, perhaps not logically entailed but nevertheless usually assumed, is that the president also owes deference to lower federal court decisions, especially those by federal courts of appeals. The president's obligation under this corollary is analogous to the duty which one lower federal court owes to treat as persuasive, if not authoritative, the opinions issued by other lower federal courts.

Judicial supremacists have focused particular attention on the problem of nonacquiescence - the executive's refusal to acquiesce in the decisions of inferior federal courts. ${ }^{8}$ Commentators such as Joshua Schwartz ${ }^{9}$ and Matthew Diller and Nancy Morawet ${ }^{10}$ claim that executive branch nonacquiescence violates the principle of separation of powers, ${ }^{11}$ arguing respectively that the Supreme Court's decisions in Crowell v. Bensen ${ }^{12}$ and Cooper v. Aaron ${ }^{13}$ foreclose executive nonacquiescence power. Daniel Coenen, in a more recent article, uses a means-ends test drawn from the system of individual rights to argue against a presidential power of nonacquiescence, on the ground that nonacquiescence

6. Not all scholars have fallen into this trap, however. See David Strauss, Presidential Interpretation of the Constitution, 15 CARDOzO L. REV. 113 (1993).

7. See Cooper v. Aaron, 358 U.S. 1, 18 (1958).

8. For a thoughtful treatment, see Samuel Estreicher \& Richard L. Revesz, Nonacquiescence by Federal Administrative Agencies, 98 YALE L.J. 679 (1989); Samuel Estreicher \& Richard L. Revesz, The Uneasy Case Against Intracircuit Nonacquiescence: A Reply, 99 YALE L.J. 831 (1990).

9. Joshua I. Schwartz, Nonacquiescence, Crowell v. Benson, and Administrative Adjudication, 77 GEO. L.J. 1815 (1989).

10. Matthew Diller \& Nancy Morawetz, Intracircuit Nonacquiescence and the Breakdown of the Rule of Law: A Response to Estreicher and Revesz, 99 YALE L.J. 801, 821-28 (1990).

11. Commentators have also argued against nonacquiescence under the Due Process Clause and the Equal Protection Clause. However, the real substance of the critique, if there is one, is the structural question of separation of powers. See Dan T. Coenen, The Constitutional Case Against Intracircuit Nonacquiescence, 75 MINN. L. REV. 1339, 1352-57 (1991).

12. 285 U.S. 22 (1932) (Constitution limits congressional delegations of judicial power to non-Article III tribunals).

13. 358 U.S. 1 (1958). 
intrudes on separation of powers values, and that the justifications advanced in support of nonacquiescence are insubstantial. ${ }^{14}$

Despite the popularity of the judicial supremacist view, its justifications are often perfectly circular. According to this view, the judiciary has final interpretive authority over the Constitution because the Supreme Court said so in Cooper, ${ }^{15}$ or because the Court held in Crowell $^{16}$ that the Constitution limits congressional delegations of judicial power to non-Article III tribunals; ${ }^{17}$ or because it intoned in Marbury v. Madison ${ }^{18}$ that "[i]t is emphatically the province and duty of the judicial department to say what the law is." But saying doesn't make it so.

The Constitution itself does not subordinate the president to the courts in matters of constitutional interpretation. On the contrary, the text and structure of the Constitution establish the president as head of a coordinate branch of the government. ${ }^{19}$ Moreover, it is perfectly clear that the president must interpret the law as an incident to enforcing it. Interpretation is not the unique province of the judicial branch. ${ }^{20}$ Deciding issues properly raised in litigation is the judicial branch's special role, but there is nothing in this function that is inconsistent with an autonomous presidential power of constitutional interpretation.

The history of checks and balances is also inconsistent with the notion of judicial supremacy in interpretation. At the time of the framing of the Constitution, the independent judiciary was an idea of recent origin. It is virtually inconceivable that the Framers intended the president to be subservient to the judiciary on matters of constitutional interpretation outside the litigation context. ${ }^{21}$ Consider also the great importance which early Congresses accorded to issues of constitutional interpretation in debates on legislation, ${ }^{22}$ or that early presidents brought to bear on their decisions to veto or sign bills presented to

14. Coenen, supra note 11 , at 1387.

15. This is essentially the position taken by Diller \& Morawetz, supra note 10, at 821-28.

16. 258 U.S. 22.

17. See Schwartz, supra note 9 , at $1835-43$.

18. 5 U.S. (1 Cranch) 137,177 (1803). See Coenen, supra note 11, at 1390 ("If more is needed to make the case against intracircuit nonacquiescence, it is supplied by Marbury v. Madison.").

19. See Strauss, supra note 6.

20. See Geoffrey P. Miller, Independent Agencies, 1986 SUP. CT. REV. 41, 66.

21. See Miller, Constitutional Theory, supra note 1, at 212, n.44.

22. The congressional deliberations on the bill to establish the first Bank of the United States provide a case in point. See generally BRAY HAMMOND, BANKS AND POLITICS IN AMERICA FROM THE REVOLUTION TO THE CIVIL WAR 115-16 (1957). 
them by Congress. ${ }^{23}$ The case for judicial supremacy in constitutional interpretation, in short, is not established.

2. Executive Supremacists. Judge Frank Easterbrook advances a powerful case for the independence of executive interpretation. ${ }^{24}$ He notes there that there is a long tradition of presidential action based on constitutional views, including views that differ from those of the courts. ${ }^{25}$

Professor Thomas Merrill offers a different justification for presidential autonomy in interpretation. His view is based on "coherentist" considerations, which "rest more comfortably within the general warp and woof of American public law."26 Professor Merrill attacks the notion that judicial opinions are "law" binding on the president, citing a number of coherentist grounds: (1) the idea is difficult to square with language used by the courts themselves; (2) judges sometimes recognize that Supreme Court opinions are not the same as the Constitution itself; (3) judicial opinions are not thought of as modifying or amending law, even when they change accepted understandings; and (4) the courts' own rule of stare decisis is not nearly as absolute as the rule of res judicata in a particular case. ${ }^{27}$

Although the executive supremacy arguments of Easterbrook, Merrill, and others are powerful and well reasoned, they suffer from objections nearly as serious as those that plague the judicial supremacy argument. If the president has fully autonomous powers to interpret the Constitution, why should he or she be subject to judicial decrees in actual cases? ${ }^{28}$ More fundamentally, complete executive autonomy would so seriously undermine the authority of the federal judiciary as an autonomous branch of government that the basic premises of the separation of powers would be threatened.

Historically, the practice of presidents has been contrary to the executive supremacy view. Although presidents have occasionally asserted their authority to interpret the Constitution in a manner inconsistent with judicial precedent, ${ }^{29}$

23. Again, the disputes over the first and second Banks of the United States provide classic examples. President Washington treated the constitutional questions attending the bill establishing the first Bank of the United States with enormous gravity. See generally HAMMOND, supra note 22, at 117-18 (President Washington took all the time allowed under the Constitution to consider the legislation sent to him for approval, "in anxious and diligent inquiries into the constitutionality of the bill and in the consideration of his duty in relation to it."). President Andrew Jackson also focused heavily on constitutional arguments (albeit with different result) in deciding to veto the bill extending the life of the second Bank of the United States. See id. at 405.

24. Frank H. Easterbrook, Presidential Review, 40 CASE W. RES. L. REv. 905 (1989-90). See also John O. McGinnis, Principle Versus Politics: The Solicitor General's Office in Constitutional and Bureaucratic Theory, 44 STAN. L. REV. 799 (1992). Former Attorney General Edwin Meese made similar arguments, and provoked a storm of controversy, in Edwin Meese, II, The Law of the Constitution, 61 TUL. L. REV. 979 (1987).

25. Easterbrook, supra note 24, at 906-11.

26. Thomas W. Merrill, The Constitutional Principle of Separation of Powers, 1991 SUP. CT. REV. $225,240$.

27. See id.

28. See Strauss, supra note 5, at 123-25.

29. See infra text accompanying notes 85-99. 
actual exercises of this power have been exceedingly rare. ${ }^{30}$ When presidents disagree with the constitutional decisions of federal courts, they appoint new judges, endorse constitutional amendments to overturn disfavored decisions, or flog the decisions from the bully pulpit of the White House. ${ }^{31}$ But they ordinarily do not take actions inconsistent with prevailing precedents. When the president asks his or her Attorney General for an opinion on the constitutionality of a particular measure, the Attorney General cites judicial opinions. ${ }^{32}$ By the same token, members of Congress cite judicial opinions when a dispute arises in Congress on the constitutionality of proposed legislation. The other branches of government act as if the opinions of the federal judiciary have special priority in the interpretation of the Constitution, a view that is nearly universally shared by persons outside the government.

3. Professor Paulsen's Dilemma. Is there any way out of the dilemma of judicial versus executive supremacy? Professor Paulsen ${ }^{33}$ argues that this blackand-white quality of existing theory is a necessary feature of any adequately developed theory of executive branch interpretation. "The premises supporting the two polar positions," Paulsen writes, "pose a sharp dilemma, forcing the principled interpreter down one slippery slope or the other." 34 Paulsen argues, in short, that there is no middle ground. A principled interpreter of the Constitution is inevitably driven toward one of the two polar positions, either judicial supremacy or executive supremacy. If Paulsen is right, then his theory precludes approaches such as the unified theory presented in this article, which claim that executive interpretive power depends on the circumstances of the case and the nature of the issue involved.

Professor Paulsen's position is ultimately unpersuasive, however, because it does not take account of unified theory values. When unified theory values are not considered, it becomes difficult, as Professor Paulsen observes, to avoid falling into one or the other of the extreme positions. As I argue below, however, when unified theory values are taken into account, a strong theoretical case can be made for an intermediate position that denies supremacy either to the executive or the judiciary over matters of constitutional interpretation. Moreover, in demonstrating the deficiency of existing theories, at least when measured against a standard of reasonable intuitions, Professor Paulsen in fact

30. Occasionally, Presidents have been willing to claim less by way of interpretive authority. See Douglas W. Kmiec, OLC's Opinion Writing Function: The Legal Adhesive for a Unitary Executive, 15 CARDOZo L. Rev. 337 (1993).

31. Presidential adherence to judicial precedent, of course, also owes much to the practicalities of governing. For an insightful discussion, see John Harrison, The Role of the Legislative and Executive Branches in Interpreting the Constitution, 73 CORNELL L. REV. 371 (1988).

32. The Attorney General cites these opinions, not as merely persuasive or analogous authority-as, for example, when the courts of one state cite decisions by courts of other states-but as, in some sense, authoritative.

33. Michael Stokes Paulsen, The Merryman Power and the Dilemma of Autonomous Executive Branch Interpretation, 15 CARDOZO L. REV. 81 (1993).

34. Id. at 83. 
provides a powerful argument for the application of unified theory, which permits the development of a modulated view of executive judicial interpretive power without using ad hoc exceptions or theoretical inconsistencies as devices for avoiding executive or judicial absolutism. ${ }^{35}$

\section{B. The Failure of Existing Theory to Recognize Internal Constraints on Presidential Interpretation}

Existing theories suffer from a problem equally fundamental as their tendency toward absolutism. The heavy focus on executive-judicial conflict tends to obscure the fact that nonjudicial tensions may also profoundly affect presidential authority to interpret the Constitution.

Presidents are empowered to interpret the Constitution whether or not their interpretations conflict with prior pronouncements of federal courts. Indeed, presidents and members of Congress must often interpret the Constitution on issues not addressed by courts in litigation. Lincoln understood this responsibility and concluded that, as a Senator, he would vote to enact a fugitive slave law, however distasteful that measure was to him personally, because he believed it compelled by the Constitution. ${ }^{36}$ A complete theory of presidential constitutional interpretation should take account of all the limits on presidential interpretive authority, including limits that stem from sources other than a perceived tension with the judicial branch. As will be discussed below, unified theory offers a satisfying account of presidential interpretive authority both within and without the context of litigation. In this respect, unified theory enjoys advantages over other theories.

\section{III}

\section{TOWARD A UNIFIED THEORY OF CONSTITUTIONAL LAW}

The theory set forth here is one example of the unified theories that have developed in the past few years. Although there are many differences between them, this article refers to them as "unified theories" because they all seek to cut across traditional rights-structure boundaries of constitutional law and resolve questions which had previously been separated in theory. Besides myself, other scholars working in the area include Akhil Amar, ${ }^{37}$ Rebecca Brown, ${ }^{38}$ Stephen

35. See infra text accompanying notes 75-105.

36. See Paul M. ANGle, CReated Equal? The Complete lincoln-Douglas Debates of 1858304 (1958). Lincoln's reasoning is discussed in Albert W. Alschuler, Holmes' Scholarship: Mr. Hyde Defines Law (manuscript on file with the author).

37. See, e.g., Akhil Amar, The Bill of Rights and the Fourteenth Amendment, 101 YALE L.J. 1193 (1992) [hereinafter Bill of Rights I; Akhil Amar, The Bill of Rights as a Constitution, 100 YALE L.J. 1131 (1991).

38. See Rebecca L. Brown, Separated Powers and Ordered Liberty, 139 U. PA. L. REV. 1513 (1991). 
Calabresi and Kevin Rhodes, ${ }^{39}$ Mary Ann Glendon and Raul Yanes, ${ }^{40}$ and Michael McConnell. ${ }^{41}$

The basic premise underlying unified theories is that we do not have two Constitutions, one devoted to questions of rights and one devoted to structure. Therefore, constitutional law should not follow two separate systems of interpretation. The systems of rights and structure have co-existed since the beginning.

The Constitution of 1787 was principally a structural document. The Framers had greater confidence in checks and balances than in parchment barriers as a safeguard of ordered liberty. Nevertheless, the Ex Post Facto Clauses ${ }^{42}$ the Bill of Attainder Clauses ${ }^{43}$ the prohibition against suspension of the writ of habeas corpus, ${ }^{44}$ the Contracts Clause ${ }^{45}$ the Treason Clauses ${ }^{46}$ the Privileges and Immunities Clause, ${ }^{47}$ the Republican Form of Government Clause, ${ }^{48}$ and the Oath or Affirmation Clause ${ }^{49}$ are all elements of the system of rights built into the original constitutional design. The Bill of Rights introduced a full-blown system of rights into the Constitution. Yet the Bill of Rights, although it sounds primarily in rights, also contains the important structural feature of the Tenth Amendment, which reserves powers to the states and the people not delegated to the federal government. ${ }^{50}$

Later amendments to the Constitution include both structural and rightsbased provisions. Among these are the various protections of rights contained in the Reconstruction Amendments, ${ }^{51}$ the structural features found in the Eleventh Amendment's restriction on federal court jurisdiction in lawsuits involving states, ${ }^{52}$ and the grants of enforcement powers to Congress under various later amendments. ${ }^{53}$

Because we have a system of fundamental law that includes both rights and structure, a reasonable interpretation of the Constitution might look to both

39. Steven G. Calabresi \& Kevin H. Rhodes, The Structural Constitution: Unitary Executive, Plural Judiciary, 105 HARV. L. REV. 1155 (1992).

40. See Mary Ann Glendon \& Raul F. Yanes, Structural Free Exercise, 90 MICH. L. ReV. 477 (1991). For subsequent comments by Professor Glendon on unified theories, see Mary Ann Glendon, The Common Law and the Written Law, in THE SUPREME COURT AND THE CONSTITUTION (Terry O. Eastland ed., 1993); Mary Ann Glendon, Comparative Law as Shock Treatment: A Tribute to Jacob W. F. Sundberg, in FESTSCHRIFT FOR JACOB SUNDBERG (Erik Nereys ed., 1993) (forthcoming).

41. Michael W. McConnell, Contract Rights and Property Rights: A Case Study in the Relationship Between Individual Liberties and Constitutional Structure, 76 CAL. L. REV. 267 (1988).

42. U.S. CONST. art. I, § 9, cl. 3; id. § 10, cl. 1.

43. Id. \& 9, cl. 3 ; id. \& 10 , cl. 1 .

44. Id. art. I, \& $9, \mathrm{cl} .2$.

45. Id. \& $10, \mathrm{cl}$. 1 .

46. Id. art. III, $\& 3$, cl. 1-2.

47. Id. art. IV, $\& 2$, cl. 1 .

48. Id. art. IV, \& 4 .

49. Id. art. II, \& 1, cl. 8.

50. Id. amend. $\mathrm{X}$.

51. Id. amends. XIII-XV.

52. Id. amend. XI.

53. Id. amend. XIII, § 2; id. amend. XIV, § 5; id. amend. XV, § 2; id. amend. XIX, § 2; id. amend. XXIII, § 2; id. amend. XXIV, § 2; id. amend. XXVI, § 2. 
systems in resolving particular constitutional questions. In general, this has not been done. Instead, constitutional law focused on one system or the other, without much attempt to unify the two.

During the nineteenth century, especially during the antebellum period, structural considerations dominated, with relatively little attention being paid to questions of rights. ${ }^{54}$ During the present century, the focus has shifted toward an emphasis on rights: property rights during the Lochner era, ${ }^{55}$ and personal liberties during more recent years.

Recently, the Supreme Court has returned to questions of structure, although maintaining primary emphasis on rights. ${ }^{56}$ With this change has come increased attention to the importance of structural issues in constitutional interpretation, leading to the development of the unified theories described above.

There are two main elements in my version of a unified theory of constitutional law. The first element is cross-fertilization. Under this element, the constitutional analyst imports the core values of the system of structure into the analysis of rights, and the core values of the system of rights into the analysis of structure.

As discussed in my earlier work, ${ }^{57}$ liberty is the principal value of the system of rights. Under unified theory, cross-fertilization mandates that questions of constitutional law be evaluated in terms of their impact, or probable impact, on individual liberties.

The focus on individual liberty is not problematic in the area of rights: In evaluating the scope of permissible warrantless searches under the Fourth Amendment, for example, it would be inconceivable for constitutional analysts to ignore the probable impact of the governing rule on the liberties of individuals to be secure in their persons, papers, or effects.

Cross-fertilization extends this analysis by requiring that considerations of individual liberties be applied in structural cases. ${ }^{58}$ In evaluating whether it is proper, under Article III of the Constitution, to vest the adjudication of common law claims in an administrative tribunal, for example, it would be appropriate for a constitutional analyst to consider whether the particular features of the federal judiciary-life tenure, salary protections, and the status of a branch of government with equal dignity in the constitutional design-make federal judges

54. It is no accident that a leading constitutional law treatise of the period was Cooley's Constitutional Limitations. THOMAS MCINTYRE COOLEY, CONSTITUTIONAL LIMITATIONS (1868).

55. Lochner v. New York, 198 U.S. 45 (1905).

56. Leading structural decisions include Mistretta v. United States, 488 U.S. 361 (1989) (upholding the organization of the United States Sentencing Commission); Morrison v. Olson, 487 U.S. 654 (1988) (upholding the independent counsel provisions of the Ethics in Government Act of 1978); Bowsher v. Synar, 478 U.S. 914 (1986) (invalidating provision of the Gramm-Rudman-Hollings Act); Immigration and Naturalization Services v. Chadha, 462 U.S. 919 (1983) (invalidating exercise of a legislative veto of executive action).

57. Miller, Constitutional Theory, supra note 1, at 202-09.

58. Justice Scalia recognized this point in Morrison, 487 U.S. at 703 (Scalia, J., dissenting) ("The purpose of the separation and equilibration of powers ... and of the unitary executive ... was not merely to assure effective government but to preserve individual freedom ...."). 
more likely to protect individual liberties than administrative officers who do not enjoy these protections. ${ }^{59}$

This question is inherently difficult to answer and depends on predictions and inferences about how particular features of a position are likely to affect official behavior. However, the issue is no more difficult, and no more empirical, than many questions of constitutional law that constitutional analysts routinely address. For example, courts consider the likelihood that the exclusionary rule will deter police misconduct; ${ }^{60}$ the chilling effect on truthful speech of a rule making private figures liable for defamation upon a lesser showing of fault than actual malice; ${ }^{61}$ or the magnitude of the threat to religious liberties created by a municipality's creche display during the Christmas season. ${ }^{62}$ Empirical issues under unified theory are not different in kind or degree.

Cross-fertilization also requires analysts to apply structural considerations in individual liberty cases. In evaluating questions arising under the system of rights, the constitutional analyst appropriately gives principal emphasis on the degree to which a given rule would affect individual liberties. But structural issues may be involved as well. Sometimes structural issues are thinly veiled beneath the surface of issues arising under the system of rights. For example, questions of whether a particular constitutional right under the Bill of Rights is incorporated against the states by the Fourteenth Amendment are ostensibly questions of rights, but the resolution of these questions necessarily involves the delicate issue of the respective powers of the states and the federal government-a pure question of structure. ${ }^{63}$ Or the question may be whether Congress has the power, under the Enforcement Clause of the Fourteenth Amendment, to expand the substance of constitutional rights beyond what the Supreme Court has recognized. ${ }^{64}$ Again, the precise point at issue in the case

59. See, e.g., Commodity Futures Trading Comm'n v. Schor, 478 U.S. 833 (1986) (upholding statute empowering an administrative agency to adjudicate common law counterclaims of the sort ordinarily determined by courts of law, and rejecting contention that such authority intruded impermissibly on the constitutional powers of the federal courts); Crowell v. Benson, 285 U.S. 22, 47-51 (1932) (construing Longshoreman's and Harbor Workers' Compensation Act narrowly to avoid an unconstitutional infringement of federal judicial power by administrative agencies).

60. See, e.g., United States v. Leon, 468 U.S. 897 (1984) (recognizing a good-faith exception to the exclusionary rule); Mapp v. Ohio, 367 U.S. 643 (1961) (holding that evidence obtained by searches and seizures in violation of the Bill of Rights is inadmissible in state criminal trials).

61. See, e.g. Wolston v. Readers Digest Ass'n, 443 U.S. 157, 163-69 (1979) (holding that individual once convicted for failure to appear before a grand jury is not a public figure); Time, Inc. v. Firestone, 424 U.S. 448, 453-55 (1976) (holding that ex-wife of corporate executive is not a public figure); Gertz v. Robert Welch, Inc., 418 U.S. 323, 347-49 (1974) (holding that lesser standard than actual malice applies to private figure plaintiffs in defamation cases, but plaintiff must still show fault to recover).

62. See, e.g., County of Allegheny v. ACLU, 492 U.S. 573 (1989) (holding that a nativity scene on the main staircase of a county courthouse violated the establishment clause); Lynch v. Donnelly, 465 U.S. 668 (1984) (holding that in the context of a seasonal display, a creche located in the heart of the city's shopping district did not violate the establishment clause).

63. See generally Bill of Rights 1, supra note 37, at 1194.

64. See, e.g., Jesse H. Choper, Congressional Power to Expand Judicial Definitions of the Substantive Terms of the Civil War Amendments, 67 MINN. L. REv. 299 (1982); Archibald Cox, Constitutional Adjudication and the Promotion of Human Rights, 80 HARv. L. REv. 91 (1966); William Cohen, Congressional Power to Interpret Due Process and Equal Protection, 27 STAN. L. REV. 603 (1975). 
may involve individual rights, but the broader underlying issues sound in structure-here, the relationship between Congress and the Supreme Court in the definition of constitutional rights.

In other cases, the structural implications of an issue are less obvious. Nevertheless, all questions of individual rights implicate structural concerns. Even an issue that appears to arise solely within the domain of rights-for example, whether under principles of equal protection, Congress can constitutionally bar women from combat duty in the military ${ }^{65}$-raises important structural issues. If the Supreme Court is asked to decide the case, the Court's willingness to determine the issue in the first place is itself an important structural decision. The implicit assertion of the power to decide the issue may seem unproblematic in light of today's jurisprudence, where Marbury $v$. Madison $^{66}$ is an unquestioned bedrock of constitutional law, but it nevertheless is not clearly established by the text of the Constitution itself. Even assuming the basic power of judicial review, it remains unclear whether the Court should have the power to adjudicate this particular question of constitutional law, implicating as it does important interests of national defense policy that might best be left for determination by the "political" branches. Even if the Court may appropriately decide this particular issue, the question remains whether the particular congeries of interests involved requires a preference rule for or against a particular result. For example, it might be the case, from a structural point of view, that the Court should defer to the judgment of the political branches on issues of national defense policy even if it decides to enter the dispute. Whichever way the Court decides this issue, it is clear that the degree of deference which it accords to the decisions of a coordinate branch of government is an important matter of structure.

These various structural considerations playing beneath the surface of individual rights jurisprudence can be summed up in the idea that the principle of checks and balances may appropriately be imported into the area of rights. The basic value served by the system of structure is the principle that the awesome powers of government are appropriately divided and directed against one another in such as way as to ensure that all power does not accumulate in a single hand, the condition which the authors of the Federalist Papers defined as the "very definition of tyranny." appropriate in each case for the constitutional analyst to consider the implications which a particular decision-including, importantly, the decision to decide the matter in the first place-has for the constitutional structure of checks and balances. If a decision threatens to unsettle the balance of powers among the branches of government, and in particular if it threatens to place essentially uncheckable powers in the hands of any one branch, then this is a reason to

65. Cf. Rostker v. Goldberg, 453 U.S. 57 (1981) (upholding against an equal protection challenge a federal statute authorizing the president to require men (but not women) to register for the draft).

66. 5 U.S. (1 Cranch) 137 (1803).

67. The Federalist No. 47, at 336 (James Madison) (Benjamin F. Wright ed., 1961). 
favor a different outcome. Again, it may be very difficult, as a practical matter, for an analyst to determine whether a decision in a given case does or does not threaten the principle of checks and balances; but, as before, this decision, however complex and uncertain, is not different from the kinds of decisions that analysts face routinely in all areas of constitutional law. There appears to be no reason in principle why the analyst could not consider the impact on checks and balances of a particular decision in the area of rights, just as the analyst would do without a second thought if the question at hand arose under the system of structure.

So far I have discussed the first level of analysis under unified theory-that of cross-fertilization. Unified theory also recognizes another, more general set of considerations that transcend the rights-structure boundary. The Constitution was intended as a document that would survive across generations; one of the pervasive themes of the Federalist Papers was that the government established by this new fundamental law must be durable enough to survive the many threats which imperil all systems of social organization. ${ }^{68}$ As analyzed in the Federalist Papers, the overriding interest in durable and stable government involves two fundamental values.

First, the authors of the Federalist Papers emphasized the absolute necessity that the government be endowed with the power to protect persons and property against violence or expropriation by others. It is for this reason, indeed, that government was established in the first place. If people were angels, we would not need government; but because people are not angels, and because they will, if given the opportunity, commit violence against others, or expropriate others' wealth, it is necessary that the people establish a collective authority with the will and the ability to prevent such violence and expropriation. The Federalist Papers refer to this quality as energy in government. ${ }^{69}$ The new government to be established by the Constitution was to be an energetic government; as such it was endowed with the authority to provide for the common defense against foreign aggression and to protect the domestic tranquility against the risk of insurrections or other private lawlessness.

At the same time, the virtue of energy in government is not unalloyed. In establishing a government and vesting it with sufficient energy to protect against foreign aggression or domestic lawlessness, the people also subjected themselves to the danger that the government would utilize this power, not for their protection, but rather to abuse them. The authors of the Federalist Papers expressed this danger of governmental abuse through the concept of factionavoidance. The abusive faction could be a minority of the people which obtains control over the government and, like a criminal clique, uses its powers to

68. See, e.g., The Federalist No. 1, at 89-92 (Alexander Hamilton) (Benjamin F. Wright ed., 1961).

69. See, e.g., id. at 92 ("... the necessity of a government at least equally energetic with the one proposed, to the attainment of this object [of preserving the union and ensuring political prosperity].") 
advance their own interests, ${ }^{70}$ or such a faction could be comprised of an aroused majority of the public which, inflamed by passions or prejudice, uses the powers of government to commit violence or expropriation against a minority. ${ }^{71}$ The authors of the Federalist Papers view factions of either sort as a severe threat to legitimate government, and advance a number of devices or mechanisms of republican government as protections against this threat. ${ }^{72}$

Taken together, the concepts of energy and faction-avoidance suggest a fundamental formula for optimal governmental design. The problem is to design a government which minimizes the sum of two costs: (1) the cost of private (or foreign) expropriation, violence, and oppression, and (2) the costs of governmental expropriation, violence, and oppression. The fundamental argument of the Federalist Papers is that the structure of government invented by the delegates at the Constitutional Convention was well suited to minimizing the sum of these costs and, thus, to solving the optimization problem.

Unified theory uses these twin concepts of energy in government and avoidance of faction as overarching criteria for evaluating particular issues of constitutional law. An interpretation of the Constitution is to be preferred if it permits the government sufficient energy to combat the threat of private or foreign expropriation, oppression, or violence. As I have argued elsewhere, the principle of energy in government can be understood as giving a constitutional dimension to the government's interest in law enforcement. This change in perspective has implications for a number of areas of constitutional law, especially constitutional criminal procedure. ${ }^{73}$ Similarly, the concern for energy in government would appear to counsel for broad governmental powers, especially executive powers, in the areas of foreign affairs, military operations, and national security policy.

The other overarching principle, that of faction-avoidance, also plays a role in unified theory. Other things equal, an interpretation of the Constitution is to be preferred that reduces the threat that a faction or coalition of factions will obtain disproportionate governmental powers and use those powers to oppress others or expropriate their wealth. Thus, in interpreting an issue arising under either the system of rights or the system of structure, the constitutional analyst should properly ask whether a particular resolution will increase the influence of faction in public life. The preferred interpretation is that which best protects against the danger that a faction or factions will obtain undue influence over the decisions or processes of government.

It should be emphasized that, despite the possible appearance of grandiosity, the claims of unified theory are in fact quite modest. Unified theory presents itself, not as a usurper of traditional constitutional interpretation, but rather as a supplement. The developed bodies of interpretation under the system of rights

70. The former communist governments in Eastern European are a classic case in point.

71. This threat is a very real possibility, or a reality, in some Eastern European countries today.

72. See THE FEDERALIST No. 9, at 124 (Alexander Hamilton) (Benjamin F. Wright ed., 1961).

73. See Miller, Constitutional Theory, supra note 1, at 222. 
and the system of structure remain fully applicable and valid within the framework of unified theory. Unified theory merely supplies considerations in addition to those offered by existing jurisprudence. Unified theory might change outcomes in some cases and, in others, might provide reasons for greater confidence in results reached through the application of traditional doctrine. At other times, its role could be seen as that of a tie-breaker: unified theory might tip the scales in favor of one result when the application of conventional doctrine leaves the constitutional analyst in equipoise. Thus, unified theory offers modest, but useful, input into constitutional analysis.

Unified theory may, however, have a greater role to play in areas where constitutional doctrine is particularly murky or unsatisfactory. The question of presidential power to interpret the Constitution is such an area. There are few cases relating to this issue and the application of traditional constitutional theory does not yield determinate results. As has been seen, theories other than unified theory tend to produce outcomes that are unacceptably extreme, either in favor of unfettered presidential authority or in favor of presidential subservience to the judicial branch. In the area of presidential interpretation of the Constitution, unified theory may have a particularly useful role to play.

\section{IV}

\section{A UNIFIED Theory of Presidential CONSTITUTIONAL INTERPRETATION}

This article now addresses the implications of unified theory for the president's power of constitutional interpretation, ${ }^{74}$ beginning with some general propositions about the nature of the executive function, moving on to a discussion of the principles of liberty, checks and balances, energy, and factionavoidance, and discussing in some detail several problems of presidential interpretive authority vis-à-vis the other branches. It also discusses the president's power to deviate from prior presidential interpretations.

A. The Nature of the Executive Function Includes the Power to Interpret the Constitution

The proposition that the president's power to execute the law includes a power of interpretation should be universally accepted. The executive is charged with carrying out the law enacted by the (legislature or by another legitimate law-creating body such as a constitutional convention). But carrying out the law

74. This problem is rendered more complex by the fact that the president himself or herself is only an individual, or the head of a relatively small office, with only a few direct constitutional powers. Many of the important questions of constitutional interpretation will arise in connection with the operations of the sprawling bureaucracy, which includes administrative agencies enjoying various degrees of ostensible independence from direct presidential oversight and control. See generally Miller, supra note 20. The question of how much power the president properly can exercise over the law-interpretation function of the administrative state is one of considerable complexity. I have attempted to address that question in other recent work, see Unitary Executive, supra note 1, and for purposes of the present article will sometimes pretermit these questions by referring to the interpretive powers of the president only. 
is not a mechanical task; it inevitably involves matters of judgment and analysis. To execute the law, the president must determine what the law means; and to determine what the law means, he or she must engage in interpretation. ${ }^{75}$ The principle of energy in government would be vitiated if the president were deprived of the authority to interpret the law as an incident to enforcement. The existence of a presidential power of interpretation should not be controversial; what is in dispute is the nature and extent of that power, especially in cases where the president's views on the meaning of the Constitution conflict with the views of some other agency of government.

\section{B. The President's Power of Interpretation Is Broader When the Issue \\ Relates to Foreign Affairs, Military Policy, or Domestic Law Enforcement}

In addition to identifying an independent source of interpretive authority in the president, the principle of energy in government suggests considerations as to the proper use of that authority. As we have seen, energy in government is needed to combat the threat of private or foreign expropriation and violence against persons or property. ${ }^{76}$ Where this threat is present, therefore, the principle of energy in government justifies a broad power in the president to interpret the Constitution in such a way as to ensure that the government is powerful enough to carry out its responsibilities. ${ }^{77}$ Thus, the president's power of constitutional interpretation is broader when the issue relates to foreign affairs, military policy, or domestic law enforcement. The president's interpretive powers are correspondingly narrower when the principle of energy in government is not strongly implicated.

\section{The President Should Interpret the Constitution to Protect Individual Liberties}

The principle of liberty, when considered under unified theory, suggests that the president should be constrained to favor interpretations of the Constitution that protect individual liberties. Identifying these interpretations may be a relatively complex matter. It may sometimes be the case that a decision in a given case will impair the liberty of one individual, while enhancing the liberties of others. Despite occasional difficulties of determining which interpretation will favor individual liberty, a general preference for liberty-enhancing interpretations appears workable and seems to fit well with reasonable intuitions about constitutional values.

75. See United States v. Nixon, 418 U.S. 683, 703 (1974) ("[I]n performance of assigned constitutional duties each branch of the government must initially interpret the Constitution."); Miller, supra note 20; Thomas W. Merrill, Judicial Opinions as Binding Law and as Explanations for Judgments, 15 Cardozo L. Rev. 43 (1993).

76. See supra note 69 and accompanying text.

77. The principle of liberty, however, operates as a check on presidential authority if the justification of energy in government seriously threatens individual liberties. 


\section{The President Should Interpret the Constitution to Reduce the Danger of Faction}

The principle of faction-avoidance also provides guidance about the proper scope of presidential constitutional interpretation. The president should favor the interpretation of the Constitution which appears most conducive to reducing the influence of faction in public life.

Consider the line-item veto. Presidents Reagan and Bush persistently sought line-item veto authority, largely for budgetary reasons. ${ }^{78}$ The constitutional text does not preclude a line-item veto. However, the president's attorneys at the Office of Legal Counsel concluded that the Constitution does not permit the president to exercise this power. ${ }^{79}$ The result may be correct under the principle of deferential interpretation because it represents a narrow reading of the Constitution in a situation where a broad reading would have greatly enhanced the president's powers vis-à-vis the Congress.

A relatively strong argument, however, could have been developed in favor of line-item vetoes. Few forms of legislation are more faction-driven than appropriations measures, and the line-item veto would provide the president with the opportunity to reduce the influence of faction by rejecting pork-barrel deals presented to him or her as part of general, essentially veto-proof legislation. The line-item veto would send these measures back to Congress for reconsideration, but the chances that the necessary majorities could be mustered to override particular vetoes would generally be low, both because of the public attention the veto would focus on the interest groups, and because the override legislation would not enjoy the same opportunities for logrolling as existed in the initial legislation. While it is true that the president could abuse the line-item veto in furtherance of factional interests, the potential for increased factional activity the line-item veto would introduce seems to be lower than the likely decrease in the power of factions it would accomplish. ${ }^{80}$ There is no indication that the Office of Legal Counsel addressed these considerations of faction-avoidance when it issued its opinion, but a full analysis should have done so, even if the conclusion that the president lacked line-item veto authority remained the same.

\section{E. Presidents Have Broad Powers to Offer Constitutional Interpretations to Courts in Litigation}

The president enjoys broad discretion to offer interpretations of the Constitution to federal courts in the context of litigation. ${ }^{81}$ When the president,

78. See Kmiec, supra note 30 , at 353.

79. The opinion is not yet published, but it is described in id. at 353-59.

80. This position is not universally shared, however. For an argument that the line item veto is subject to serious problems of faction, see Louis Fisher \& Neal Devins, How Successfully Can the States' Item Veto be Transferred to the President?, 75 GEO. L.J. 159, 190 (1986) (line item vetoes at the federal level may exacerbate problems of logrolling).

81. For a contrary view, see Arthur S. Miller, The President and Faithful Execution of the Laws, 40 VAND. L. REV. 389, 401 (1987). 
through the Solicitor General or other designated official, makes arguments to the Supreme Court, the effect is not to enforce the law but merely to suggest interpretations that the Supreme Court has discretion to accept or reject. This view is somewhat controversial because of the wide-spread belief that the Solicitor General is somehow special in the litigation process-that he or she is, in Lincoln Caplan's arresting if inaccurate phrase, a "tenth Justice." 82 While it may seem obvious that the president and his or her subordinates in the Department of Justice have special responsibilities to interpret the Constitution responsibly when making arguments to the Supreme Court, I believe the actual situation is different. The role of the Solicitor General appears to impose special interpretive responsibilities only when it is forgotten that the president always has significant constraints on his or her interpretive discretion, both within the context of litigation and without. ${ }^{83}$

\section{F. Presidents May Disobey the Mandates of Federal Courts Only in Extraordinary Circumstances}

Once a federal court has decided a case and issued its mandate to the executive branch, unified theory suggests that the president has no authority directly to flout a mandate of a federal court in a case properly in its jurisdiction, except, in the most unusual circumstances.

Presidential disobedience to a federal court order raises a number of red flags in unified theory. For starters, it has extremely problematic consequences for the principle of checks and balances. The power of a federal court to adjudicate cases and controversies arising within its jurisdiction is one of the principal checks in our constitutional system against the danger of excessive accumulation of power in the hands of the president. If the president could ignore the mandates that issue from such adjudications, on the ground that he or she disagrees with the constitutional interpretations on which the adjudications are based, the result would be a potential breakdown of the system as a whole, because a fundamental check on self-interested behavior by the president would be lost. ${ }^{84}$

82. Lincoln Caplan, The Tenth Justice: The Solicitor General and the Rule of LAW (1987). Even former Solicitors General sometimes endorse the notion that their job carries a special weight in interpretation that has a higher dignity than the president's general obligation to interpret the Constitution in a responsible fashion. Reading between the lines, this appears to be one of the themes of Charles Fried's interesting and provocative account of his tenure as Solicitor General in the Reagan Administration. See CHARLES FrIED, ORDER AND LAw: ARguING THE REAGAN REvolution-A FIRSTHAND ACCOUNT (1991). For a critique, see John O. McGinnis, Principle Versus Politics: The Solicitor General's Office in Constitutional and Bureaucratic Theory, 44 STAN. L. REV. 799 (1992).

83. See ANGLE, supra note 36.

84. It should be noted that the danger of presidential disobedience to judicial directives is especially problematic, from the standpoint of checks and balances, when the matter is one of constitutional interpretation rather than statutory construction. If the matter is one of statutory construction, an action by the president in refusing to comply with a judicial mandate, on the ground that the court has misinterpreted the statute, can be trumped by congressional legislation clarifying the meaning of the statute (the president, of course, could refuse to comply with such a trumping statute as well, but that is a different matter, and essentially signals a breakdown of the constitutional system). When a question 
In addition to concerns under the rubric of checks and balances, the principle of faction avoidance also counsels strongly against any presidential authority, absent situations of national crisis, to disobey otherwise valid mandates of the Supreme Court. Of all the agencies of the government, the Court is perhaps the least vulnerable to the influence of faction. Because the Justices serve for good behavior and enjoy salary protections, they need not account to any political interest group for their behavior once on the Court. The Court, moreover, sits en banc, a rule that tends to protect against the possibility that a particular interest group will obtain disproportionate influence over its decisions. In a case where the Supreme Court has come to a direct confrontation with the president, it is more likely that the president, and not the Court, is serving the interests of a particular faction.

On the other hand, the concern for maintaining energy in government suggests that there may be extraordinary situations in which the president could legitimately disregard an otherwise binding ruling by the Supreme Court. If the Supreme Court, for example, issued a writ prohibiting the president as Commander-in-Chief from protecting the Hawaiian Islands against attack from a hostile foreign power-perhaps on the theory that a formal declaration of war is necessary before any military action can take place-the president would be justified in ignoring the writ and protecting United States territory against the aggression. This action would not represent a breakdown in the constitutional fabric, but rather an exercise of authority vested in the president to act, even contrary to the Supreme Court, in cases of dire threat to the national security. Because of the threat of factionalism and inappropriate accumulation of power in the executive, this authority to ignore binding judicial judgments must, under unified theory, be strictly limited to cases of imminent threat to the national security. One need only consider the unfortunate history of other countries which, although ostensibly ruled by written constitutions, have been governed for extended periods by executive fiat under self-serving claims of national emergency, to recognize the peril that attends any exercise by the president of the power to ignore judicial judgments.

What, then, are we to make of the famous case about which Professor Paulsen has written with such panache: ${ }^{85}$ President Lincoln's refusal to honor judicial process in Ex parte Merryman? ${ }^{86}$ Lincoln suspended the writ of habeas corpus at a time when Congress was out of session, and federal military officers arrested and imprisoned numerous citizens believed to be secessionists. Merryman, one of those detained, sought and obtained a writ of habeas corpus from Chief Justice Roger Taney. The writ directed the commanding officer at Fort McHenry to produce the petitioner, but the officer refused, citing the

of constitutional interpretation is involved, there is no course of action that Congress can take to change the president's interpretation, or to resolve the constitutional confrontation, short of impeaching the president or the members of the Court, or initiating the procedure for constitutional amendment.

85. See generally Paulsen, supra note 33.

86. 17 F. Cas. 144 (D. Md. 1861) (No. 9,487). 
President's order. Taney held the officer in contempt and ruled that President Lincoln had no power to suspend the writ of habeas corpus, since that power was vested, in Taney's view, in Congress alone. Recognizing that his order would not be enforced, Taney directed that the record of the proceedings be transmitted to the President personally, leaving it to him, "in fulfillment of his constitutional obligation to 'take care that the laws be faithfully executed,' to determine what measures he will take to cause the civil process of the United States to be respected and enforced." 87

Did Lincoln properly have the power, under unified theory, to disregard the writ of the Chief Justice in Merryman? Arguably, unified theory can justify Lincoln's action on the ground that, under the circumstances, the suspension of the writ of habeas corpus was a compelling necessity for the preservation of the nation, notwithstanding the facts that the liberty of a citizen was being infringed and that the President's action, if extended to other circumstances, potentially undermined the principle of checks and balances. At the time Lincoln acted, as documented by Professor Paulsen, the nation's capital was threatened by armed secessionists, federal troops had been menaced by a mob in Baltimore, and Lincoln himself had been forced to enter the capital surreptitiously. ${ }^{88}$ In such extraordinary circumstances, the President was arguably justified in suspending the writ and in refusing to comply with Chief Justice Taney's arguably selfinterested decree. ${ }^{89}$ Indeed, Lincoln himself justified his actions in exactly these terms. In a speech to Congress, Lincoln suggested that it was permissible, and even constitutionally required, for the President to refuse to execute a law in order that the government not be overthrown..$^{90}$

It does not follow, however, from the conclusion that Lincoln may have been justified in ignoring Taney's decree in Merryman, that a president may willy-nilly ignore binding federal court decrees. The fact that presidents have almost never done so is a telling indication that the power to ignore a judicial decree is an extraordinary authority available only as a last resort. The only other recorded case of presidential nonacquiescence presents an instructive contrast. President Jackson reportedly rejected the Supreme Court's decree in Worcester $v$. Georgia ${ }^{91}$ which held that federal treaties with the Cherokee Nation barred the State of Georgia from exercising legislative jurisdiction over whites living in Cherokee territory. ${ }^{92}$ If Lincoln was justified in Merryman, what of Jackson?

87. Id. at 153 .

88. See generally Paulsen, supra note 33.

89. Taney was the author of the Dred Scott opinion which Lincoln, as President, had vowed to resist.

90. See 4 Roy P. Basler, The Collected Works of Abraham Lincoln 431 (1953), quoted in Paulsen, supra note 33 ("Would not the official oath be broken, if the government should be overthrown, when it was believed that disregarding the single law, would tend to preserve it?").

91. 31 U.S. (6 Pet.) 515 (1832).

92. See G. EdWard White, The Marshall Court and Cultural Change, 1815-35, at 737 n.234 (1988). 
Initially, it should be noted that the procedural context in Worcester was quite different from that in Merryman. The latter case involved a direct judicial order to an executive official-and implicitly to the President-to take a particular action on pain of contempt of court for nonacquiescence. Nothing of the sort was presented in Worcester, which did not directly involve any executive official at all. The order of the Supreme Court in that case merely purported to nullify the actions of the State of Georgia in sentencing the plaintiff in error to hard labor. It was the Georgia authorities, not the President, who flouted the Court's decree. ${ }^{93}$

It could be said that the order of the Court was a law of the United States or, alternatively, that the treaties involved were laws of the United States, which the President had a duty to execute under the Take Care Clause. ${ }^{94}$ However, the Take Care Clause cannot mean that the president has the duty to execute every law of the United States without exception. Many laws go unexecuted all the time, without anyone raising an objection. The Department of Justice routinely overlooks violations of federal law under principles of prosecutorial discretion. Executive agencies frequently fail to comply with time deadlines set forth in environmental laws. ${ }^{95}$ The situation in which the president has failed to execute a law is quite different from one in which he or she has refused a binding judicial order to take or refrain from taking a particular action.

In Worcester, for example, it would have been a different case if the plaintiff in error, upon failing to obtain satisfaction from the Georgia authorities, had obtained a writ of mandamus or other order from a federal court directing a federal executive branch official to force his release from state custody. If such an order had been obtained, and the President had directed that it be disobeyed, the case would have been similar to Merryman. But President Jackson was never placed under a binding obligation of this sort. ${ }^{96}$ When Georgia refused to release Worcester, he initially sought to bring the matter once again to the attention of the Court, with the expectation that the Court would request that the President enforce the mandate. ${ }^{97}$ Worcester changed his mind, however, and obtained a pardon from the Governor of Georgia, thus mooting the controversy. ${ }^{98}$ President Jackson was never formally requested, much less ordered, to enforce the decree. The Merryman power was never implicated.

It is evident, under principles of unified theory, that President Jackson would have been acting unconstitutionally if he refused such a direct order in Worcester, even if the President justified his action on the ground that he disagreed with the Supreme Court's interpretation of applicable law. The concern for energy in

93. Id.

94. U.S. CONST. art. I, $\S 3$ (President shall "take care that the laws be faithfully executed").

95. See, e.g., William V. Luneberg, Petitioning Federal Agencies for Rulemaking: An Overview of Administrative and Judicial Practice and Some Recommendations for Improvement, 1988 WIS. L. REV. $1,16$.

96. For an account of the imbroglio, see WHITE, supra note 92, at 737-39.

97. Id. at 738 .

98. See id. 
government would not justify such an action, since there was no threat of insurrection or imminent danger to national security, and the integrity of the nation was not going to crumble if Georgia was denied legislative jurisdiction over Cherokee lands within its borders. Moreover, the dangers of factionalism were high in this case: Powerful interests in Georgia were seeking Cherokee lands, and the Cherokees and their supporters, such as the plaintiff in error in Worcester, a missionary from Vermont, were evidently politically powerless. The concern for individual liberties also strongly counseled against President Jackson's action, since the Georgia authorities had committed the plaintiff in error to four years at hard labor for no other crime than preaching the gospel in Cherokee territory without first obtaining a license and swearing allegiance to the state.

Thus, the premises of unified theory suggest that Lincoln may well have been correct in refusing Taney's decree in Merryman, but that Jackson would have acted unconstitutionally if he had violated a judicial order to enforce Marshall's judgment in Worcester. Unified theory permits a nuanced analysis of cases that yields different results depending on the particular facts and circumstances, results that seem to jibe with reasonable intuitions about outcomes.

\section{G. Outside the Litigation Context, Presidents Should Generally Defer to Settled Judicial Precedent}

In other cases, the president or a subordinate will be asked to interpret the Constitution before a case finds its way into court but in a situation where the issue is susceptible to judicial review. ${ }^{99}$ Unified theory suggests that presidents should generally defer to settled judicial interpretations unless there are strong reasons to decide otherwise. ${ }^{100}$ Settled judicial interpretations appear relatively insulated from the dangers of faction. Although factions can influence courts through lobbying on appointments, filing judicial briefs, or manipulating public opinion, their influence on courts is probably less direct than is their influence on the "political" branches. Thus, deferring to settled judicial interpretations would tend to serve the unified theory value of faction-avoidance. Further, it seems reasonable to conclude that settled judicial interpretations tend to be liberty enhancing. Courts have a tradition of protecting individual liberties. The nature of the judicial process, in which the affected individual receives equal dignity as a litigant with the state, tends to correct for the imbalance of power that might exist in the political arena. Thus, the value of liberty which is fundamental to unified theory also counsels in favor of presidential deference to settled judicial interpretations.

The implications of the two other principal elements of unified theory are not as clear-cut. The principle of checks and balances suggests some reasons for

99. For a helpful discussion of this situation, see Strauss, supra note 6, at 115 .

100. Here, because the President acts in the shadow of the courts, practical considerations also counsel in favor of decisions congruent with existing judicial precedent. 
deference to settled judicial interpretations, but also some reasons for allowing the president a significant degree of interpretive flexibility in situations where the president's decision is reasonably susceptible to judicial review. In favor of deference is the fact that the federal judiciary is an autonomous branch of the government with no formal power other than the power to issue judgments which would not mean much if they were restricted in effect to the narrow facts before the court. The degree of deference owed to settled interpretations, under the principle of checks and balances, would evidently depend on the nature of the court involved, with the greatest deference owed to the Supreme Court and the least to trial-level courts. Deference would also vary according to and on the closeness of fit between prior judicial opinions and the facts before the president, with greater deference owed in a case on all fours with prior decisions and less deference owed in a case with significant factual differences.

On the other hand, the principle of checks and balances does not act univocally in this context. If the issue is reasonably susceptible to judicial review, the courts will probably have the opportunity to issue a judgment in the future, thus placing the president in the position of defying an ostensibly binding mandate of a court of competent jurisdiction if he or she wishes to adhere to the original interpretation. Because the federal judiciary possesses the power to check the president's action in the future, the president should enjoy somewhat greater freedom of action, under the principle of checks and balances, than he or she would otherwise. If the president's decision is not reasonably susceptible to judicial review, the case for deference to settled judicial interpretations is stronger because the courts will have no subsequent opportunity to reject the president's interpretation.

The value of energy in government, however, could potentially justify a president in refusing to adhere to a settled judicial interpretation. If the president concludes that the government cannot effectively fulfill its mandate to combat private expropriation and violence, or to safeguard national interests in the arena of foreign or military affairs, then the president could, consistent with unified theory, determine to repudiate a settled judicial interpretation. However, because the other values of unified theory generally support presidential adherence to settled judicial precedent, the president's power to ignore such a precedent should be limited to situations where there are strong reasons to reject the prior decisions.

H. The President Has Broad Discretion to Evaluate the Constitutionality of

Proposed Legislation, But in General Should Support the

Constitutionality of Enacted Legislation

The president must frequently interpret legislation or proposed legislation, and in so doing must consider whether the legislation is constitutional. Where the legislation is only proposed, the president owes little deference to its constitutionality, since Congress as a body has not yet spoken and will have the opportunity to consider the president's views when it does take up the proposal. 
In the case of enacted legislation, however, the situation is different. In general, the principle of checks and balances suggests that the president should defer to the legislative judgment that particular provisions are constitutional. This is an application of the rule of deferential construction to avoid conflicts with other branches. The president's obligation to enforce legislation despite constitutional difficulties would appear to be stronger in cases in which Congress has given due attention to the constitutional problems, and approved the legislation with full awareness of the difficulties, than in cases where the constitutional problems were overlooked or not carefully considered.

In some cases, however, unified theory would not call for as much deference to the constitutionality of legislation. If the legislation in question trenches on individual liberties, the president can properly draw on the principle of liberty to interpret the legislation in a liberty-enhancing manner, or even to refuse enforcement, if the president believes the measure violates some constitutional protection of personal liberties or property rights. Similarly, if the legislation deprives the president of powers to safeguard the national defense, conduct military operations, or protect the public against domestic insurrection or violence, the president need not defer to the congressional judgment that such legislation is constitutional. ${ }^{101}$ The president may not have to defer to congressional judgments of constitutionality in the case of legislation that is clearly designed to benefit one interest group at the expense of another, or of the public at large. ${ }^{102}$ In such a case, the principle of faction-avoidance justifies a broader power of presidential interpretation than would otherwise be allowed. Further, the president should enjoy stronger powers of interpretation when legislation significantly encroaches on the president's constitutional authority. While unified theory generally supports a rule of deferential construction in cases in which the constitutional provision in question affects the rights and prerogatives of another branch of government, if the president concludes that the Congress has itself intruded on executive prerogatives, the president should not be disabled from protecting these prerogatives. ${ }^{103}$

101. A classic example is the War Powers Resolution, containing a number of measures which presidents have opposed on the ground that they deny the president the necessary powers to commit United States forces to armed conflict short of war. See generally Charles Bennett et al., Panel Discussion, The President's Powers as Commander-in-Chief versus Congress' War Power and Appropriations Power, 43 U. MIAMI L. REv. 17 (1988).

102. See, e.g., Geoffrey P. Miller, The True Story of Carolene Products, 1987 SUP. CT. REV. 397 (federal filled milk legislation serving the special interest of the U.S. dairy industry).

103. The problem is similar to strategy of tit-for-tat in prisoners' dilemma games, under which a player cooperates as long as the other player cooperates, and does not cooperate whenever the other player does not cooperate. Tit-for-tat has been shown to be an effective strategy in iterated prisoners dilemma games. See generally ROBERT M. AXELROD, THE EVOLUTION OF COOPERATION (1984). 


\section{Absent Substantial Reason, Presidents Should Adhere to Consistent Executive Branch Precedent}

If there is prior jurisprudence in the executive branch, the degree to which the president is bound by prior interpretations should depend on the nature and circumstances of the prior interpretation. The guiding rules here can be drawn, perhaps, from the principle of energy in government. By binding himself or herself with formal, public interpretations of the law, the president can actually enhance the energy by which he or she enforces the law, because the president's commitment to a particular interpretation provides notice to those who might be the target of enforcement efforts as to what the president expects or does not expect. If presidents changed their minds at random, or for reasons of whim or caprice, the energy of the executive would arguably be decreased despite the apparent increase in discretion that an unfettered power to change the law would seem to imply. Thus, the principle of energy in government might impose limits on the president's ability to deviate from an interpretation of the Constitution previously issued by the executive branch.

The president cannot, however, be absolutely locked into prior interpretations. Changed conditions or unforeseen exigencies may demand a fresh look at the problem, and new administrations need a reasonable degree of flexibility to implement their own policies, free of strictures that may have been imposed by potentially hostile former administrations.

The degree to which the president should be constrained in interpreting the Constitution by prior executive branch pronouncements would appear to depend, in part, on the nature of the prior interpretation. Formal interpretations by the Attorney General or the Office of Legal Counsel probably should be given greater weight than interpretations of other executive branch agencies because the power to give legal opinions to the president has been, to a significant extent, centralized in those offices. Interpretations by "independent" agencies should also have force, although, as I argue in a different article, ${ }^{104}$ the degree to which the president ought to be bound by the lawmaking of administrative agencies is a much more complex question than the raw issue of whether the head of the agency enjoys statutory protection against presidential removal. Interpretations by former administrations are probably less authoritative than interpretations by the current administration, although the principle of energy in government suggests that presidents should not deviate from constitutional interpretations issued by prior administrations unless there are good reasons to do so.

104. See Miller, Unitary Executive, supra note 1, at 212-18. 


\section{$\mathrm{V}$ \\ CONCLUSION}

This article has addressed the president's power of constitutional interpretation from the standpoint of a unified theory of constitutional law. Unified theory provides some guidance on this question that is not available in the existing literature. The theory supports results that are generally consistent with reasonable intuitions about the proper scope of presidential interpretive powers. It does not fall into the trap of endorsing either absolute presidential powers or absolute judicial powers, offering instead a modulated set of prescriptions that vary depending on the circumstances under which the president faces a question of constitutional interpretation. Unified theory, moreover, provides a relatively comprehensive set of concepts that apply to many different interpretive settings, including important settings in which the constitutional question is unlikely to receive judicial attention.

While unified theory offers some advantages, this article does not present it as any kind of panacea. Unified theory does not displace existing jurisprudence, but rather operates only as a supplement. The result will usually be the same after the application of unified theory as before. Moreover, as I have remarked elsewhere, the concepts of unified theory are couched at such a high level of generality as to make the application of the theory to particular fact settings uncertain in many cases. ${ }^{105}$ Its concepts might prove indeterminate, or even susceptible to result-oriented manipulation. While these are dangers, they are not unique to unified theory. If unified theory suffers criticism from being too general, it at least offers the hope of identifying sensible considerations for constitutional analysts to examine when addressing difficult and perplexing issues of fundamental law.

105. See Miller, Rights-Structure, supra note 1, at 223. 
